\title{
Computer Design of Robot ABB IRB 140 Transport System from Manufacturing Point of View
}

Jozef Novak-Marcincin, Miroslav Janak, Dominik Takac

Faculty of Manufacturing Technologies, Technical University of Kosice, Bayerova 1, 08001 Presov, Slovakia. E-mail: jozef.marcincin@tuke.sk

This paper presents the theoretical and practical aspects of industrial robots transport systems problems focused on application possibilities connected with concrete type of robotic device. Introduction of the article presents today possibility of robot transport systems and collect information about basic technical parameters of transport systems, their design and construction. Main part describe industrial robot ABB IRB 140, collect information about technical parameters, its construction, axes, motions and applications used in industrial practice. Practical part of paper is focused on proposal of robot transport system design from manufacturing point of view.

Key words: industrial robot, transport system, manufacturing technology

\section{Acknowledgements}

Ministry of Education, Science, Research and Sport of SR supported this work, contract VEGA No. 1/0032/12, KEGA No. 002TUKE-4/2012 and ITMS project 26220220125.

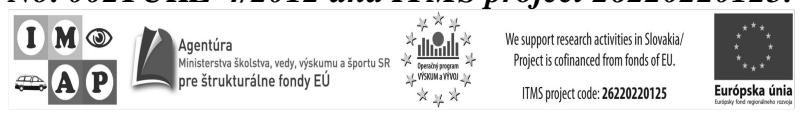

\section{References}

[1] ONG, S. K. (2012). Interactive Robot Trajectory Planning and Simulation Using Augmented Reality, Robotics and Computer-Integrated Manufacturing, Vol. 28, No. 2, pp. 227-237, ISSN 0736-5845.

[2] ONG, S. K. (2010). A novel AR-based robot programming and path planning methodology, Robotics and Computer-Integrated Manufacturing, Vol. 26, No. 3, pp. 227-237, ISSN 0736-5845.

[3] NOVAK-MARCINCIN, J., NOVAKOVA-MARCINCINOVA, L. (2013). Advanced techniques for NC programs preparation. Applied Mechanics and Materials, Vol. 389, pp. 726-729, ISSN 1660-9336.

[4] BOROS, T., LAMAR, K. (2012). Six-axis educational robot workcell with integrated vision system, LINDI 2012 - IEEE International Symposium on Logistics and Industrial Informatics, Art. no. 6319495, pp. 239-244.

[5] BILEK, O., SAMEK, D., KNEDLOVA, J. (2013). Offline programming for robotic deburring process of aluminium. Manufacturing Technology, Vol. 13, No. 3, pp. 269-275, ISSN 1213-2489

[6] ABB (2008). IRBT X004, Data sheet. Available on: http://www.abb.sk/product/seitp327/569910 ed39487cb6c12574360040afa9.aspx? productLanguage $=$ sk\&country $=$ SK.

[7] ABB (2012). IRB 140, Data sheet. Available on: internete: http://www05.abb.com/global/scot/scot241.nsf/ veritydisplay/d7dfcc72e3fd760dc12579c7002ce1e0/\$file/PR10031EN\%20R14\%20LR.pdf.

[8] LAMAR, K., NESZVEDA, J. (2013). Average probability of failure of a periodically operated devices. Acta Polytechnica Hungarica, Vol. 10, No. 8, pp. 153-167, ISSN 1785-8860.

[9] BeDNAROVA, V., LICHY, P., ELBEL, T., LANA, I. (2013). Production and properties of metal foams from non-ferous metals alloys. Manufacturing Technology, Vol. 13, No. 3, pp. 262-265, ISSN 1213-2489.

[10] VOJTKO, I., KOCISKO, M., JANAK, M., FECOVA, V. (2013). The new design of robot arm, SAMI 2013 - IEEE International Symposium on Applied Machine Intelligence and Informatics, Art. no. 6480943, pp. 53-56.

[11] PETRUSKA, P., NOVAK-MARCINCIN, J., DOLIAK, M. (1997). ROANS - intelligent simulation and programming system for robots and automated workcell. Proceedings of the IEEE International Conference on Intelligent Engineering Systems INES, pp. 451-456, ISBN 0-7803-3627-5.

[12] BARNA, J., FECOVA, V., NOVAK-MARCINCIN, J., TOROK, J. (2012). Utilization of Open Source Application in Area of Augmented Reality Assembling Processes. Manufacturing Technology, Vol. 12, No. 12, p. 2-7, ISSN 1213-2489. 
[13] NOVAK-MARCINCIN, J., JANAK, M., BARNA, J., TOROK, J., NOVAKOVA-MARCINCINOVA, L., FECOVA, V. (2012). Verification of a Program for the Control of a Robotic Workcell with the Use of AR. International Journal of Advanced Robotics Systems, Vol. 9, Art. No. 54, ISSN 1729-8806.

[14] NOVAK, M., KASUGA, H., OHMORI, H. (2013). Differences at the Surface Roughness by the ELID and Grinding Technology. Manufacturing Technology, Vol. 13, No. 2, pp. 210-215, ISSN 1213-2489.

[15] NOVAK-MARCINCIN, J., DOLIAK, M., HLOCH, S., ERGIC, T. (2010). Application of the Virtual Reality Modelling Language to Computer Aided Robot Control System ROANS. Strojarstvo, Vol. 52, No. 2, pp. 227-232, ISSN 0562-1887.

[16] NOVAK-MARCINCIN, J., BRAZDA, P., JANAK, M., KOCISKO, M. (2011). Application of Virtual Reality Technology in Simulation of Automated Workplaces. Tehnicki Vjesnik, Vol. 18, No. 4, pp. 577-580, ISSN 13303651 .

[17] NOVAK-MARCINCIN, J., TOROK, J., BARNA, J., NOVAKOVA-MARCINCINOVA, L. (2012). Technology of Perspective Scanning Methods for Realization of 3D Models of Manufacturing Devices. Manufacturing Technology, Vol. 12, No. 13, pp. 186-191, ISSN 1213-2489.

[18] NOVAK-MARCINCIN, J., FECOVA, V., BARNA, J., JANAK, M., NOVAKOVA-MARCINCINOVA, L. (2013). Using of the virtual reality application with the scanning device Kinect for manufacturing processes planning. Manufacturing Technology, Vol. 13, No. 2, 2013, p. 215-219, ISSN 1213-2489.

[19] NOVAK-MARCINCIN, J., JANAK, M., FECOVA, V., NOVAKOVA-MARCINCINOVA, L. (2013). Utilization of Augmented Reality Elements for Visualization of Operational States of Manufacturing Devices. Applied Mechanics and Materials, Vol.. 308, pp. 111-114, ISSN 1662-7482.

[20] NOVAK-MARCINCIN, J., FECOVA, V., NOVAKOVA-MARCINCINOVA, L., TOROK, J., BARNA, J. (2013). Verification of Machine Position in Production Plant with Use of Virtual Reality Technology. Applied Mechanics and Materials, Vol.. 308, pp. 171-174, ISSN 1662-7482.

[21] NOVAK-MARCINCIN, J., BARNA, J., TOROK, J., JANAK, M. (2013). Visual Reconstruction and Optimization of Real Wokplace on the Base of Spatial Digitisation. Applied Mechanics and Materials, Vol.. 308, pp. 175-178, ISSN 1662-7482.

[22] NOVAK-MARCINCIN, J., BARNA, J., TOROK, J. (2014). Precision assembly process with augmented reality technology support. Key Engineering Materials, Vol. 581, pp. 106-111, ISSN 1662-9795.

[23] NOVAK-MARCINCIN, J., TOROK, J., NOVAKOVA-MARCINCINOVA, L. (2014). New possibility of visualization in mechanical engineering. Applied Mechanics and Materials, Vol. 442, pp. 209-215, ISSN 1660-9336.

[24] NOVAK-MARCINCIN, J., NOVAKOVA-MARCINCINOVA, L. (2014). Collision detection application for virtual and augmented reality aided manufacturing system. Applied Mechanics and Materials, Vol. 464, pp. 338-344, ISSN 1660-9336.

[25] NOVAK-MARCINCIN, J., JANAK, M. (2014). Design and realization of robot workplaces with virtual and augmented reality application. Advanced Materials Research, Vol. 853, pp. 613-618, ISSN 1662-8985. 